\title{
Facial biometrics: a novel technique for evaluation of morphological changes in orofacial Crohn's disease
}

\author{
Oluyori Kutulola Adegun, ${ }^{1,2}$ Lifong Zou, ${ }^{3,4}$ Amanda Willis, ${ }^{4}$ Farida Fortune ${ }^{1}$
}

${ }^{1}$ Clinical and Diagnostic Oral Sciences, Institute of Dentistry, Barts and the London School of Medicine and Dentistry, Queen Mary University of London, London, UK ${ }^{2}$ Centre for Medical Education, Newham University Teaching Hospital, Barts Health NHS

Trust, London, UK

${ }^{3}$ Adult Oral Health, Institute of Dentistry, Barts and the London School of Medicine and Dentistry, Queen Mary University of London, London, UK

${ }^{4}$ Institute of Dentistry, Royal London Hospital, Barts Health NHS Trust, London, UK

\section{Correspondence to} Professor Farida Fortune, f.fortune@qmul.ac.uk

\section{DESCRIPTION}

Crohn's disease presents in the orofacial region with a characteristic lip swelling that can progress to facial disfigurement. ${ }^{12}$ To date, assessments of these changes are based on clinical observation together with patient satisfaction reports and semiquantitative methods. Although useful, the development of an analytical approach that permits objective, reproducible and quantitative evaluation of morphological changes is required.

We report the use of facial biometrics to objectively quantify changes associated with orofacial Crohn's disease in a 28-year-old woman. ${ }^{3}$ The patient was referred by the gastroenterologist for treatment of repeated upper lip swelling. In this patient a baseline facial scan was acquired when minimal lip swelling was present (figure 1A). Two months later she represented with markedly increased perioral swelling and a second scan was captured (figure 1B). Utilising coordinate metrology, figure $1 \mathrm{~A}, \mathrm{~B}$ were identically positioned and registered. This allowed areas of swelling to be visualised (figure $1 \mathrm{~b}$ ) and a defined patient-specific template (highlighted in figure $1 \mathrm{~b}-\mathrm{e}$ ) to be generated. An initial intralesional triamcinolone injection $(40 \mathrm{mg} / \mathrm{mL})$ resulted in some resolution of the swelling; a volume reduction of $6540.8 \mathrm{~mm}^{3}$ (figure 1c) postregistration of the third scan (figure 1C) against the second was noted. Four months after the third scan, the upper lip swelling recurred (figure 1D), with the right side more severely affected (figure 1d). This informed the precise position (* in figure 1D) for guided infiltration of intralesional triamcinolone $(40 \mathrm{mg} / \mathrm{mL})$. Two weeks post-treatment, registration of figure $1 \mathrm{D}, \mathrm{E}$ revealed a volume reduction of $9656.4 \mathrm{~mm}^{3}$. At this point she reported considerable satisfaction with the outcome of treatment.

\section{Learning points}

Crohn's disease is a relapsing systemic inflammatory disease with gastrointestinal lesions occurring anywhere from the mouth to the anus.

- Facial biometrics offers a non-radiating, non-contact, non-invasive, quick and cost-effective modality for routine evaluation, objective quantification of responses to therapy and long-term follow-up of the orofacial Crohn's disease.

Contributors All authors contributedin preparing, editing and finalising the manuscript.

\section{Competing interests None.}

Patient consent Obtained.

Provenance and peer review Not commissioned; externally pee reviewed.

\begin{tabular}{|c|c|c|c|c|c|}
\hline & $1^{\text {st }}$ Scan (Baseline) & $2^{\text {nd }}$ Scan & $3^{\text {rd }}$ Scan & $4^{\text {th }}$ Scan & $5^{\text {th }}$ Scan \\
\hline \multicolumn{6}{|l|}{ Facial Scans } \\
\hline \multicolumn{6}{|l|}{\begin{tabular}{|c} 
Registered Scans \\
(with template)
\end{tabular}} \\
\hline Volume changes & & $+11335.87 \mathrm{~m}$ & $+4795.11 \mathrm{~m}$ & $+9407.52 \mathrm{~m}$ & $-248.86 \mathrm{mr}$ \\
\hline
\end{tabular}

To cite: Adegun OK, Zou L, Willis $A$, et al. BMJ Case Rep Published online: [please include Day Month Yearl doi:10.1136/bcr-2013010460
Figure 1 (A-E) Facial scans acquired at five different but successive appointments. (b-e) Scans postregistration of the second, third, fourth and fifth (B-E) facial scans against the baseline scan (A). The template refers to a consistent measurement location from which volume changes were calculated across the registered scans (b-e). The colour scale spans from light purple to blue (left side) and yellow to red (right side) representing negative to positive morphological changes, respectively. 


\section{REFERENCES}

1 Tilakaratne WM, Freysdottir J, Fortune F. Orofacial granulomatosis: review on aetiology and pathogenesis. J Oral Pathol Med 2008;37: $191-5$
2 Sanderson J, Nunes C, Escudier M, et al. Oro-facial granulomatosis: Crohn's disease or a new inflammatory bowel disease? Inflamm Bowel Dis 2005;11:840-6.

3 Zou L, Adegun OK, Willis A, et al. Facial biometrics of peri-oral changes in Crohn's disease. Lasers Med Sci. Published Online First: 24 Feb 2013. doi:10.1007/s10103013-1286-5

Copyright 2013 BMJ Publishing Group. All rights reserved. For permission to reuse any of this content visit http://group.bmj.com/group/rights-licensing/permissions.

BMJ Case Report Fellows may re-use this article for personal use and teaching without any further permission.

Become a Fellow of BMJ Case Reports today and you can:

- Submit as many cases as you like

- Enjoy fast sympathetic peer review and rapid publication of accepted articles

- Access all the published articles

- Re-use any of the published material for personal use and teaching without further permission

For information on Institutional Fellowships contact consortiasales@bmjgroup.com

Visit casereports.bmj.com for more articles like this and to become a Fellow 